\title{
Doubling Your Monetary Base and Surviving: Some International Experience
}

\author{
Richard G. Anderson, Charles S. Gascon, and Yang Liu
}

\begin{abstract}
The authors examine the experience of selected central banks that have used large-scale balancesheet expansion, frequently referred to as "quantitative easing," as a monetary policy instrument. The case studies focus on central banks responding to the recent financial crisis and Nordic central banks during the banking crises of the 1990s; others are provided for comparison purposes. The authors conclude that large-scale balance-sheet increases are a viable monetary policy tool provided the public believes the increase will be appropriately reversed. (JEL E40, E52, E58)
\end{abstract}

Federal Reserve Bank of St. Louis Review, November/December 2010, 92(6), pp. 481-505.

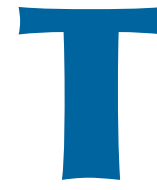

he recent financial crisis has challenged monetary policymakers around the world on a scale that has not been seen since the 1930s. In normal times, the monetary policy for most central banks is implemented by (i) targeting an overnight interest rate and (ii) holding as assets securities issued by the country's own national treasury. In some cases, a central bank's assets also include foreign exchange or other nations' sovereign debt. When large shocks occur and in response the policy rate has already been reduced to (near) zero, some central banks have aggressively expanded their balance sheet, a policy widely referred to as quantitative easing. ${ }^{1}$ In the United States, for example, the Federal Reserve's mid-2010 balance sheet was approximately triple its size of two years earlier.

The essence of quantitative easing policies is the purchase of assets from the private sector with newly created central bank deposits; such exchanges promise to reduce both risk and term premia in longer-term interest rates. ${ }^{2}$ The cur- rently sparse empirical evidence suggests that quantitative easing actions likely must be large because the private-sector's substitution elasticities among high-quality financial assets are small.

In this article, we examine the experience of selected central banks that have used large-scale balance-sheet expansion as a policy instrument. We conclude that such increases are a viable monetary policy tool for central banks with significant independence and credibility, assuming the public believes the increase will be appropriately reversed.

To some analysts, large balance-sheet increases raise the specter of higher inflation. Historically, an absence of fiscal discipline was the cause of large-scale increases in central bank balance sheets. Sargent (1982), for example, reviews cases of hyperinflation and Meltzer (2005) reviews monetary policy in the United States dur-

2 See Bernanke, Reinhart, and Sack (2004). Purchasing lower-quality assets raises discussion of the boundary between monetary and fiscal policy. Recent academic papers include those by Jeanne and Svensson (2007), Cúrdia and Woodford (2010a,b), Gertler and Karadi (2009), Reis (2009), Borio and Disyatat (2009), and Söderström and Westermark (2009).

1 See Bernanke and Reinhart (2004).

Richard G. Anderson is an economist and vice president, Charles S. Gascon is a research support coordinator, and Yang Liu is a research associate at the Federal Reserve Bank of St. Louis.

(C) 2010, The Federal Reserve Bank of St. Louis. The views expressed in this article are those of the author(s) and do not necessarily reflect the views of the Federal Reserve System, the Board of Governors, or the regional Federal Reserve Banks. Articles may be reprinted, reproduced, published, distributed, displayed, and transmitted in their entirety if copyright notice, author name(s), and full citation are included. Abstracts, synopses, and other derivative works may be made only with prior written permission of the Federal Reserve Bank of St. Louis. 
ing the late 1960s and 1970s. Recent actions in the United States, United Kingdom, Switzerland, Australia, and others have proactively used massive balance-sheet changes as a policy tool while sustaining a commitment to avoid rapid inflation.

\section{SOME MACROECONOMIC THEORY}

Our principal lesson-that large, visible money injections made in response to special events can increase near-term economic activity without increasing inflation if policymakers credibly commit to reverse the increase at a later datearises in a variety of macro models. The key element is that inflation expectations are little affected by increases in central bank balance sheets that are perceived as temporary. Goodfriend and King (1981) showed this result in the context of Barro's (1976) rational expectations model by introducing a central bank that credibly commits to a long-run path for the money stock even while sharply increasing the near-term money supply. ${ }^{3}$ Recently Berentsen and Waller (2009) showed the same result in a search-theoretic real business cycle model. ${ }^{4}$ In contrast, many early rational expectations macroeconomic models (during the 1970s) specified that all changes in the money supply were unanticipated and permanent-that is, the money stock followed a random walk. In such models, changes in the money stock, because they were anticipated to be permanent, caused the price level to jump and real economic activity to remain unchanged. Similar results arise in the classical long-run equilibria of New Keynesian models that contain incomplete information and

\footnotetext{
3 Specifically, Goodfriend and King (1981, p 382) outline a mechanism by which "for a given wealth, an individual who suffers an anticipated temporary reduction in measured real balances might shift expenditure from present to future periods, in order to take advantage of lower net costs of transactions in these periods." Presumably a sharp but temporary increase in money balances provided by the central bank might induce individuals to shift expenditure to present from future periods to take advantage of now-lower costs in the present period.

4 The Berentsen-Waller model (2009) is based on the Lagos-Wright double coincidence of wants framework. Monetary policy is assumed to have short-run and long-run components, the former focused on stabilizing real activity (in the presence of shocks) and the latter on the long-run inflation trend.
}

adjustment costs, although there may be interim increases in economic activity. ${ }^{5}$

A central bank's promise to reverse a largescale balance-sheet increase in a timely fashion lacks credibility if the central bank is not sufficiently independent of the political process.

Although earlier studies tended to be equivocal regarding a negative correlation between inflation and central bank independence, more recent research using longer sample periods and broader measures has found stronger correlations (Crowe and Meade, 2008). Central banks that have used quantitative easing successfully rank high on measures of independence, transparency, and accountability. Laurens, Arnone, and Segalotto (2009), for example, ranked 98 central banks on these characteristics-successful central banks (except Australia) tended to rank at or above the 15th percentile. The Sveriges Riksbank (Sweden) and the Swiss National Bank (SNB) are ranked 4 th and 5th, respectively. The Reserve Bank of Australia (RBA), however, ranked 48th.

\section{CASE STUDIES: SUCCESSFUL LARGE-SCALE BALANCE-SHEET INCREASES}

This section explores the practical use of large-scale balance-sheet increases as a policy instrument. Selected countries with recent largescale central bank balance-sheet increases are shown in Table $1 .{ }^{6}$ A subset of these countries is explored in greater detail. The countries loosely fall into three groups: (i) countries that responded in a temporary manner to the recent financial crisis, (ii) the Nordic countries during the banking

\footnotetext{
5 See, for example, Woodford (2003) and Clarida, Galí, and Gertler (1999). Among the differences in these papers noted by Berentsen and Waller $(2009$, p. 2$)$ is that New Keynesian models rely on "nominal rigidities, such as price or wage stickiness, that allows monetary policy to have real effects" and that the models "are 'cashless' in the sense that there are no monetary trading frictions." In their general equilibrium real business cycle model, all prices are flexible but money overcomes trading frictions. Hence, in New Keynesian models, ad hoc stickiness may allow real effects of monetary shocks even under complete information.

6 The currency symbols used throughout the text are listed in Table 1. Unless otherwise indicated, monetary values are listed as U.S. dollars.
} 


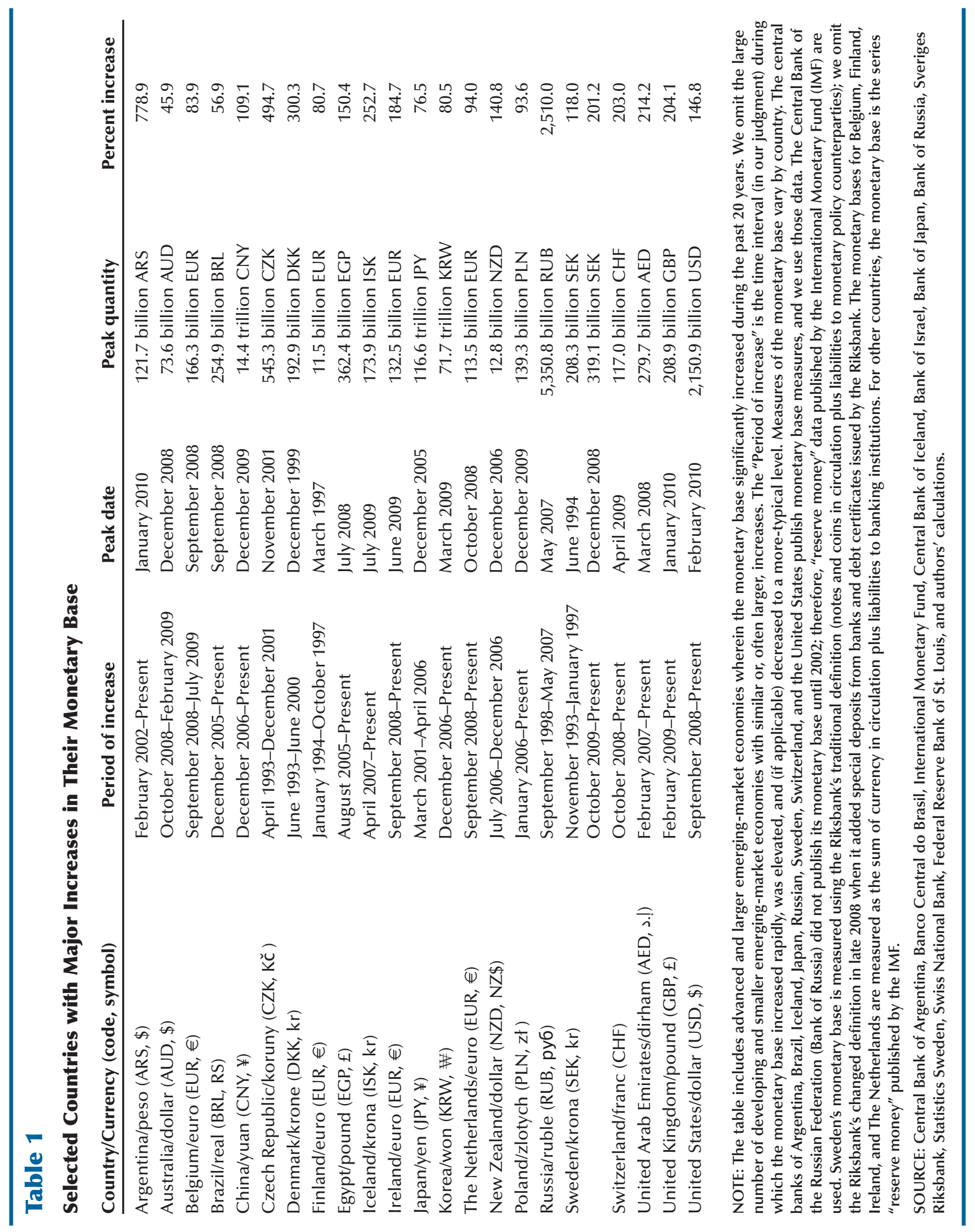


Figure 1

\section{Doubling of the Monetary Base in Selected Countries}
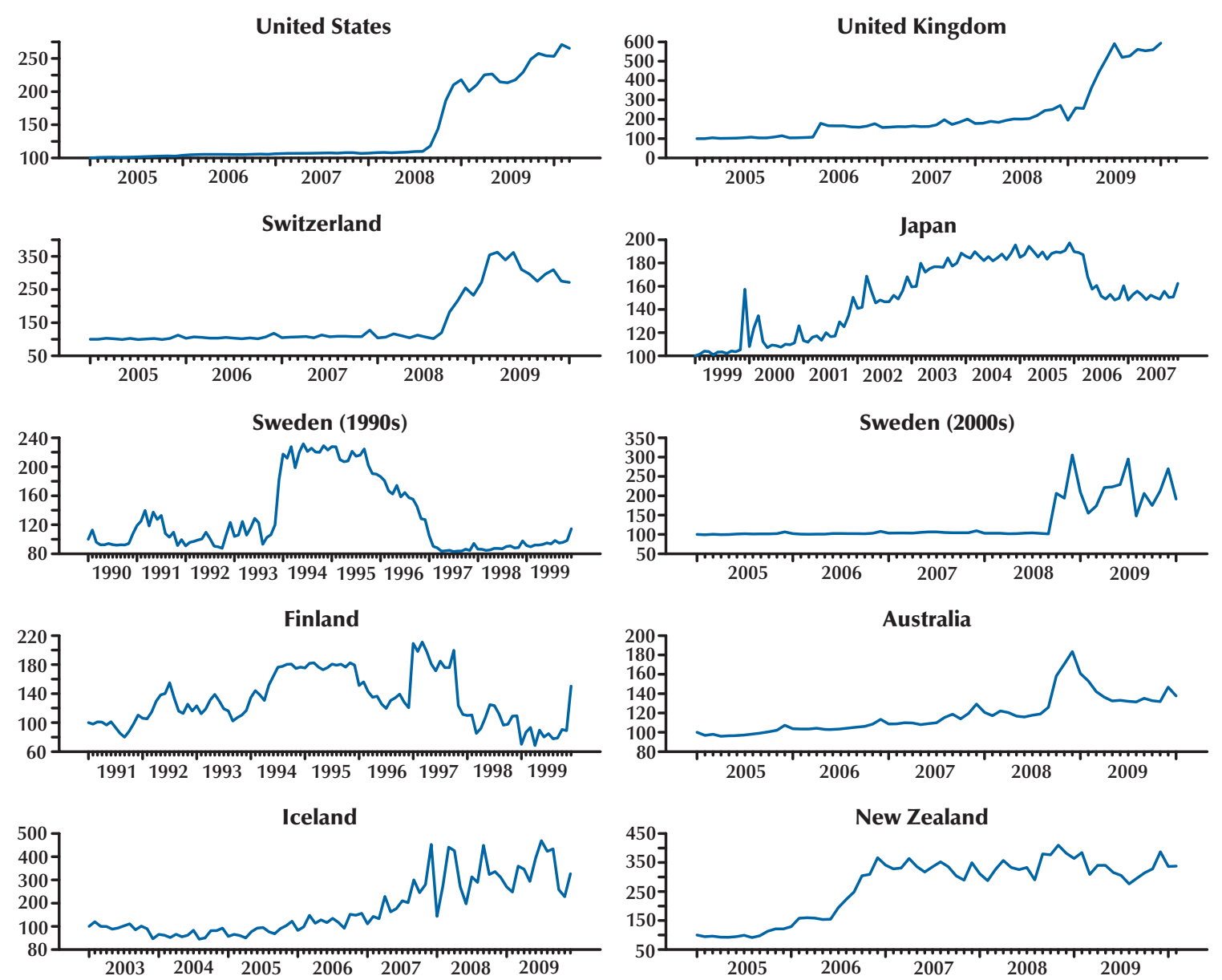

NOTE: The figure displays 10 cases of extraordinary monetary base changes in nine countries. To illustrate clearly the magnitude of the change, in each panel the monetary base series is indexed (normalized) to 100 at the first observation. The horizontal (time) scale varies by country, reflecting primarily four different episodes. Changes in the United States, the United Kingdom, Switzerland, Sweden (2000s), Iceland, and Australia reflect the 2008 global financial crisis. Changes in Finland and Sweden during the 1990s reflect the Nordic banking crisis. Changes in Japan reflect its quantitative easing from 2001-06. Finally, New Zealand increased its monetary base permanently in 2006 to improve operation of its payment system.

SOURCE: Federal Reserve Board, Bank of England, Swiss National Bank, Bank of Japan, Sveriges Riksbank, International Monetary Fund, Central Bank of Iceland, Reserve Bank of Australia, and Reserve Bank of New Zealand. 


\section{Figure 2}

\section{Central Bank Policy Rates}
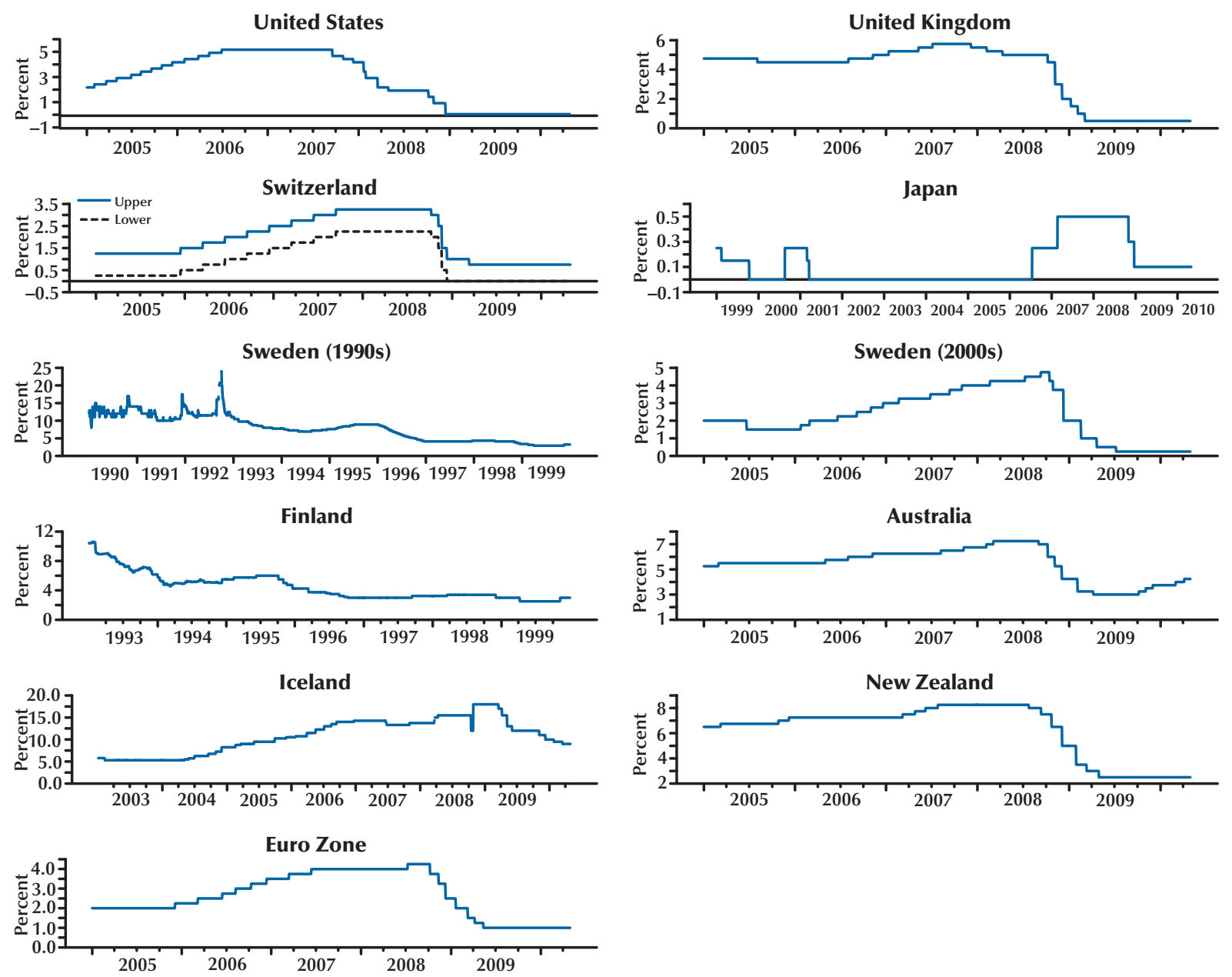

NOTE: The figure displays central bank policy rates in nine countries and the euro zone. In some cases, dramatic decreases in policy target rates accompanied expansions of the monetary base. In others, changes were modest (e.g, Australia and New Zealand). In the 1990s, foreign exchange crises occasionally caused sharp increases in policy rates not accompanied closely by changes in the monetary base (e.g., Sweden and Finland). The Bank of Japan kept the uncollateralized overnight call rate as low as $\mathbf{0}$ percent during the quantitative easing period.

Rates shown (daily data): United States, federal funds rate; United Kingdom, Bank Rate; Switzerland, target range of 3-month LIBOR rate; Japan, uncollateralized overnight call rate; Sweden, marginal rate (January 1990-May 1994), and repo rate (June 1994-present); Finland, tender rate (January 1993-December 1998), and minimum bid rate of the European Central Bank's main financing operation (January 1999-present); Australia, interbank overnight cash rate; Iceland, nominal discount rate; New Zealand, Official Cash Rate; euro zone, minimum bid rate of the European Central Bank's main financing operation. Sweden's official interest rate topped 50 percent in September 1992 as the result of the Riksbank's exchange rate defense. We omit observations of Sweden's marginal rate that are higher than 24 percent.

SOURCE: Federal Reserve Board, Central Bank of Iceland, Bank of England, Swiss National Bank, Bank of Finland, Bank of Japan, European Central Bank, Bank of Russia, Riksbank, Reserve Bank of Australia, Reserve Bank of New Zealand. 
Figure 3

\section{Actual and Expected Inflation}
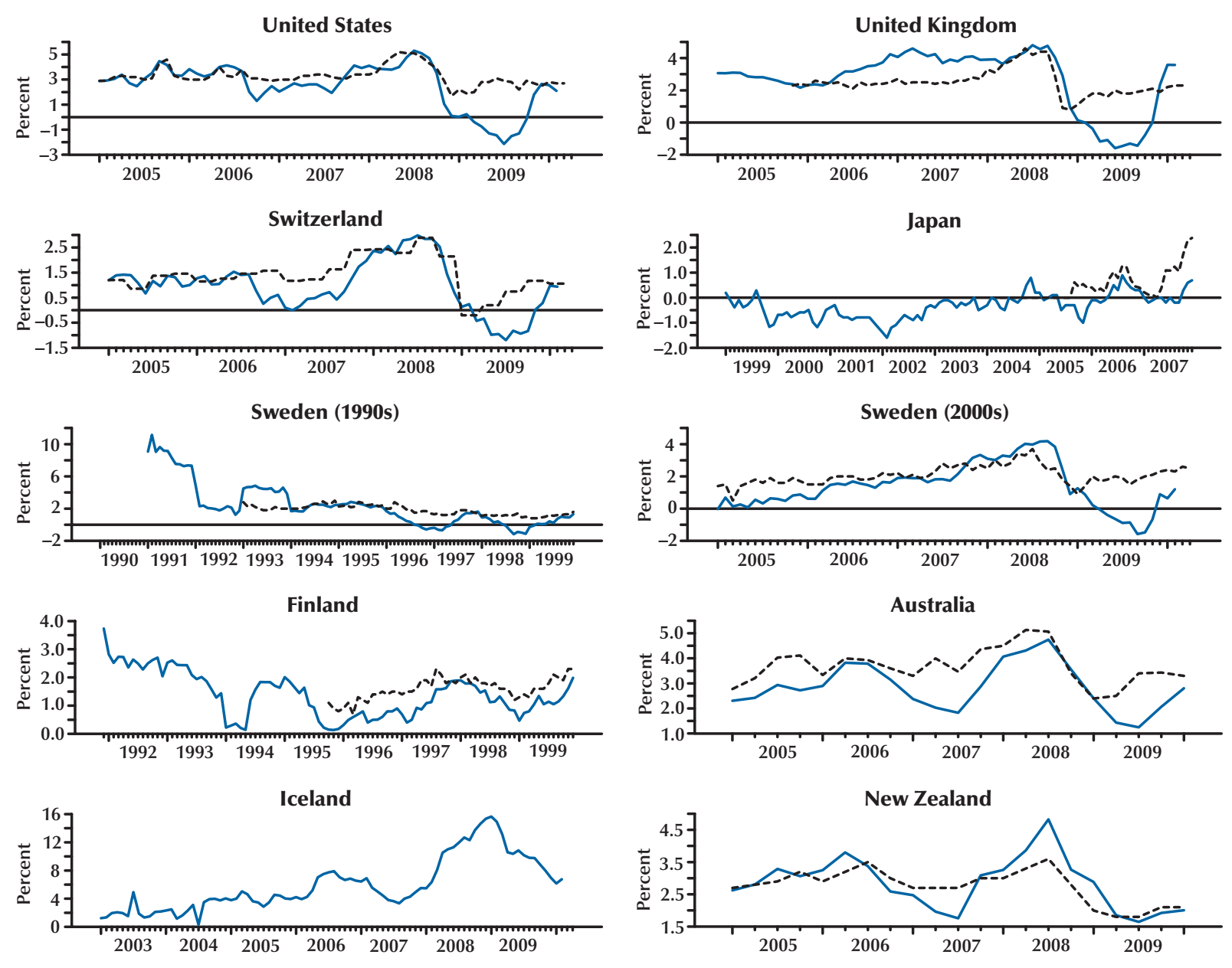

- Consumer Price Inflation: Year-over-year increase in consumer prices (monthly)

--- Expected Inflation: Anticipated change in consumer prices during the next 12 months (monthly)

SOURCE: United States, Survey of Consumers conducted by Thomson Reuters and the University of Michigan; United Kingdom, Citigroup Inflation Tracker conducted by YouGov and Citigroup; Australia, Melbourne Institute Survey of Consumer Inflationary Expectations conducted by the Melbourne Institute of Applied Economic and Social Research; New Zealand, Survey of Expectations conducted by the Reserve Bank of New Zealand; Sweden, Consumer Tendency Survey conducted by the National Institute of Economic Research; Finland, Consumer Survey conducted by Statistics Finland; Japan, Consumer Confidence Survey conducted by the Economic and Social Research Institute. Values of expected inflation in Japan are calculated using the median of the anticipated change in consumer prices during the next 12 months. Switzerland, Consumer Confidence Survey by the State Secretariat for Economic Affairs. Switzerland's Consumer Confidence Survey reports an index of expected inflation. Data are transformed into an index with a mean equal to the mean consumer price inflation series over the observed period. 


\section{INFLATION EXPECTATIONS}

Well-anchored inflation expectations are crucial to the success of unconventional monetary policy actions, including large increases in central bank balance sheets. Figure 3 shows both consumer price inflation and expected inflation for selected countries that have experienced such increases. Actual inflation is measured as the year-over-year increase in consumer prices. Expected inflation is the anticipated change in consumer prices during the next 12 months as determined from household surveys. We selected household surveys based on their availability across countries. Other surveys are available. A cross-country comparison of inflation expectations is routinely included in the IMF's World Economic Outlook. The Reserve Bank of New Zealand's Survey of Expectations is a market-based survey, whereas all other surveys are household based. A comparison of household surveys and market surveys can be found in Batchelor and Dua (1989).

The onset of financial crisis and recession typically reduces both actual and expected inflation. At the same time, if expansionary monetary policies are anticipated to stimulate economic activity, households might expect that actual inflation will return to its long-run trend in the near future. This pattern is evident in most of the countries we surveyed.

During 2008, for example, the United States, the United Kingdom, Switzerland, Sweden, and Australia experienced sharp decreases in actual and expected inflation. At the end of 2008, expected inflation generally stabilized (albeit at a lower rate than the recent trend) even as actual inflation continued to fall. As economic activity stabilized during 2009, inflation expectations increased (particularly in the second quarter), even while actual inflation continued to ease. Higher expectations were somewhat validated by higher inflation during the second half of 2009. It appears that both actual and expected inflation had returned to the long-run trends by the end of 2009 .

The 1990s Nordic banking crisis is another example. Inflation in Sweden and Finland was high in 1990 and 1991. As Swedish and Finnish central banks and governments pursued aggressive expansionary policy, consumer price inflation declined below these central banks' inflation targets. The National Institute of Economic Research in Sweden and Statistics Finland started to survey inflation expectations in 1993 and 1995, respectively. In both countries, expected inflation was stable around the respective central bank's inflation target.

crisis of the 1990s, and (iii) selected other countries, for comparison, with (apparently) permanent increases. Figure 1 shows changes in the monetary base of these countries during periods of quantitative easing (each country's series is normalized to 100 at the date when major balance-sheet expansion began). ${ }^{7}$ Sweden's monetary base during the Nordic banking crisis of the 1990s, for example, rapidly doubled and remained at that level for two years before slowly returning to its pre-expansion level. Japan's monetary base increased slowly starting in 2001 and fell rapidly

7 Generally, the monetary base is defined as the sum of currency in circulation outside the central bank plus deposits of financial institutions at the central bank. Variations for individual countries are noted in the case studies. in 2006 when the Bank of Japan (BOJ) reversed policy. New Zealand, in a cooperative agreement with its banks to improve operation of the payment system, doubled its monetary base to a new, sustained level.

Large-scale balance-sheet increases in response to financial crises often occur after policymakers have reduced their target interest rate to (near) zero; the paths of central bank policy rates are shown in Figure 2. During December 2008, for example, the BOJ reduced its target overnight interest rate to 0.1 percent and the Federal Reserve reduced its target federal funds rate to a range between zero and 0.25 percent. Exceptions are Australia and Iceland, which are discussed later. 


\section{Anderson, Gascon, Liu}

The inflation experience in these countries is shown in Figure 3, which displays both actual inflation and survey-based measures of expected inflation. Consistent with the visibility of the financial crisis and high credibility levels of these central banks, inflation expectations moved little, if at all, as balance sheets increased-indeed, the time series for actual and anticipated inflation are nearly indistinguishable.

\section{The United States ${ }^{8}$}

Before September 2008, the size of the Federal Reserve's balance sheet had changed little during the financial crisis of 2007-08 because holdings of Treasury securities decreased as lending through credit-market programs increased (Figure 4). In September, the Fed ceased shrinking its Treasury portfolio and large-scale balance-sheet increases began. In turn, the federal funds rate slipped steadily; on December 16, 2008, the Federal Open Market Committee (FOMC) set a target range for the federal funds rate of 0 to 0.025 percent. On November 25, 2008, the Federal Reserve announced that it would purchase up to $\$ 100$ billion of debt issued by the Federal Home Loan Banks, FNMA, and FHLMC, plus up to $\$ 500$ billion of mortgage-backed securities (MBS) backed by FNMA, FHLMC, and GNMA with the stated purpose to "reduce the cost and increase the availability of credit for the purchase of houses."9 Purchases began in January 2009.

As of late January 2009, the Federal Reserve's total assets and liabilities were approximately $\$ 2$ trillion versus $\$ 900$ billion in late August 2008; purchases of housing-related debt and MBS accounted algebraically for about one-third of the increase and a variety of credit and lending programs accounted for the rest.

At its March 17-18, 2009, meeting the FOMC announced its intent to purchase by year-end

\footnotetext{
8 See Bernanke (2009) for a summary of the U.S. experience.

9 GNMA (Government National Mortgage Association, or "Ginnie Mae”), part of the U.S. Department of Housing and Urban Develop ment, issues no debt but does issue MBS on which it guarantees payment of principal and interest. FNMA (Federal National Mortgage Association, or "Fannie Mae") and FHLMC (Federal Home Loan Mortgage Corporation, or "Freddie Mac") issue both debt and MBS on which they guarantee the timely payment of principal and interest.
}

2009 up to $\$ 1.25$ trillion of agency MBS and up to $\$ 200$ billion of agency debt, plus up to $\$ 300$ billion in longer-term Treasury securities during the next six months. These purchases, later referred to as the Large-Scale Asset Purchase program, sustained the size of the Fed balance sheet even as various credit and lending programs closed. As of the April 2010 FOMC meeting, total assets were $\$ 2.34$ trillion.

\section{United Kingdom}

Rapid expansion of the U.K.'s monetary base began in February 2009, eventually tripling to $£ 208.04$ billion in July 2009 from $£ 68.69$ billion in January 2009. Motivating aggressive increases in the monetary base was a sharp slowing in economic activity: Real output during 2008:Q4 and 2009:Q1 fell at 7 percent and 10 percent annual rates, respectively. The Bank of England (BOE)'s Monetary Policy Committee (MPC) had reduced its policy rate (Bank Rate) from 5 percent in October 2008 to 1 percent in February 2009. ${ }^{10}$ Yet, forecasts suggested an increased risk that inflation might undershoot the MPC's 2 percent target.

In March, the MPC decided to ease monetary conditions in the United Kingdom by reducing Bank Rate to 0.5 percent and to begin aggressive expansion of its balance sheet. The Bank's first purchase was $£ 75$ billion of government bonds (gilts) during the first week of March. During March, the Bank purchased £982 million of commercial paper, $£ 128$ million of commercial bonds, and $£ 12.9$ billion of gilts. The monetary base rose to $£ 90.12$ billion by the end of March. ${ }^{11}$ By the end of May, additional purchases pushed the BOE's total assets close to $£ 300$ billion and the monetary base to $£ 156.14$ billion.

Figure 5 shows the impact of these programs on the BOE's balance sheet and the monetary base.

\footnotetext{
${ }^{10}$ Before March 5, 2008, the U.K. Asset Purchase Facility (APF) purchased $£ 986$ million in commercial paper. Because these purchases were financed by the sale to the public of Treasury bills, and hence had little impact on the monetary base, we omit them from our analysis. For details of the APF's operation, see BOE (2009a,b).

${ }^{11}$ In 2006 the BOE discontinued publication of its monetary base, referred to as Mo. Here, we calculate the monetary base as the sum of BOE banknotes in circulation plus deposits of banks at the BOE (reserves).
} 


\section{Figure 4}

\section{Composition of Federal Reserve Balance Sheet}
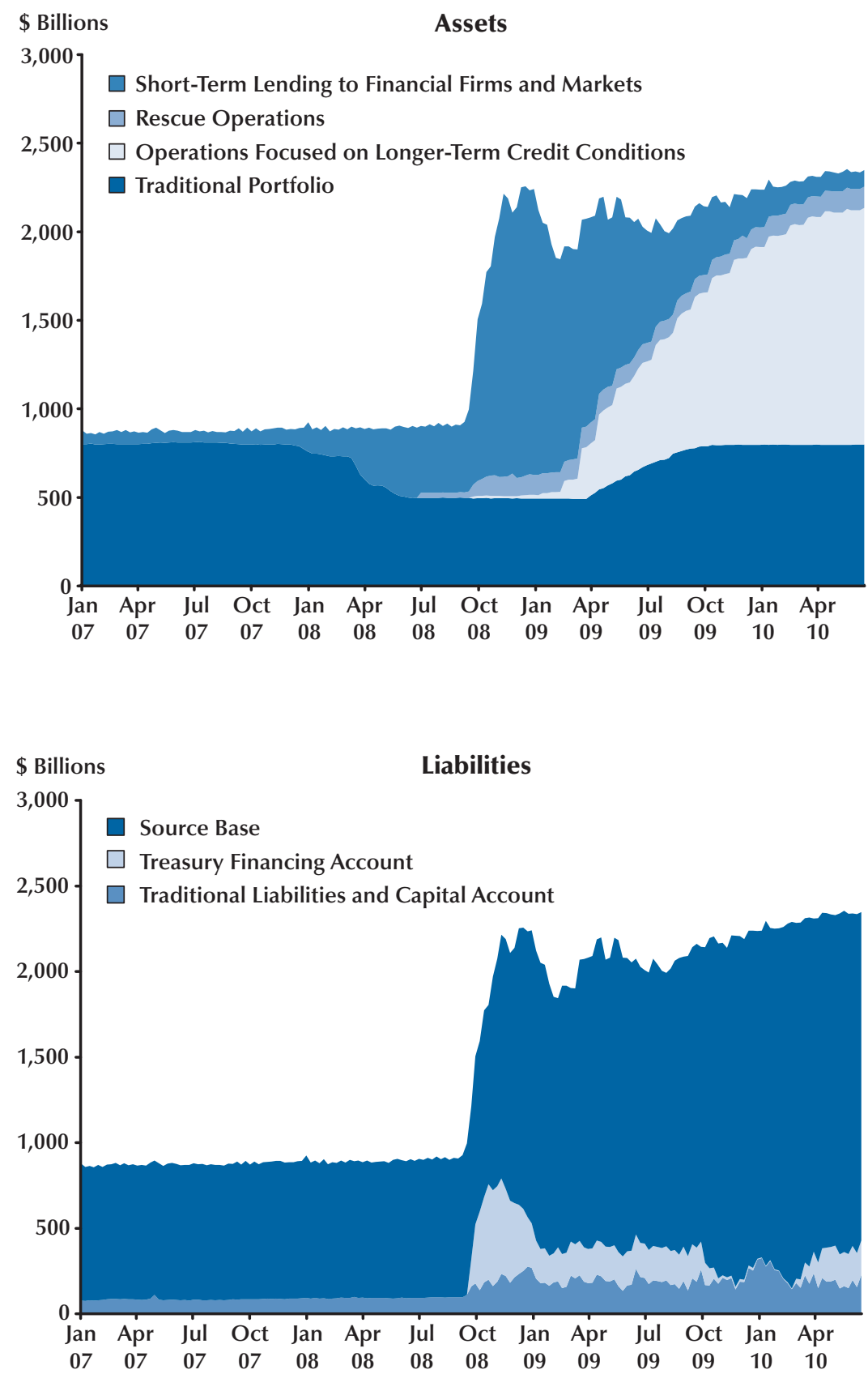

NOTE: See Federal Reserve Bank of St. Louis, U.S. Financial Data, for a description of chart categories. SOURCE: Federal Reserve Board, Federal Reserve Statistical Release H.4.1. 
Figure 5

\section{Composition of Bank of England Balance Sheet}
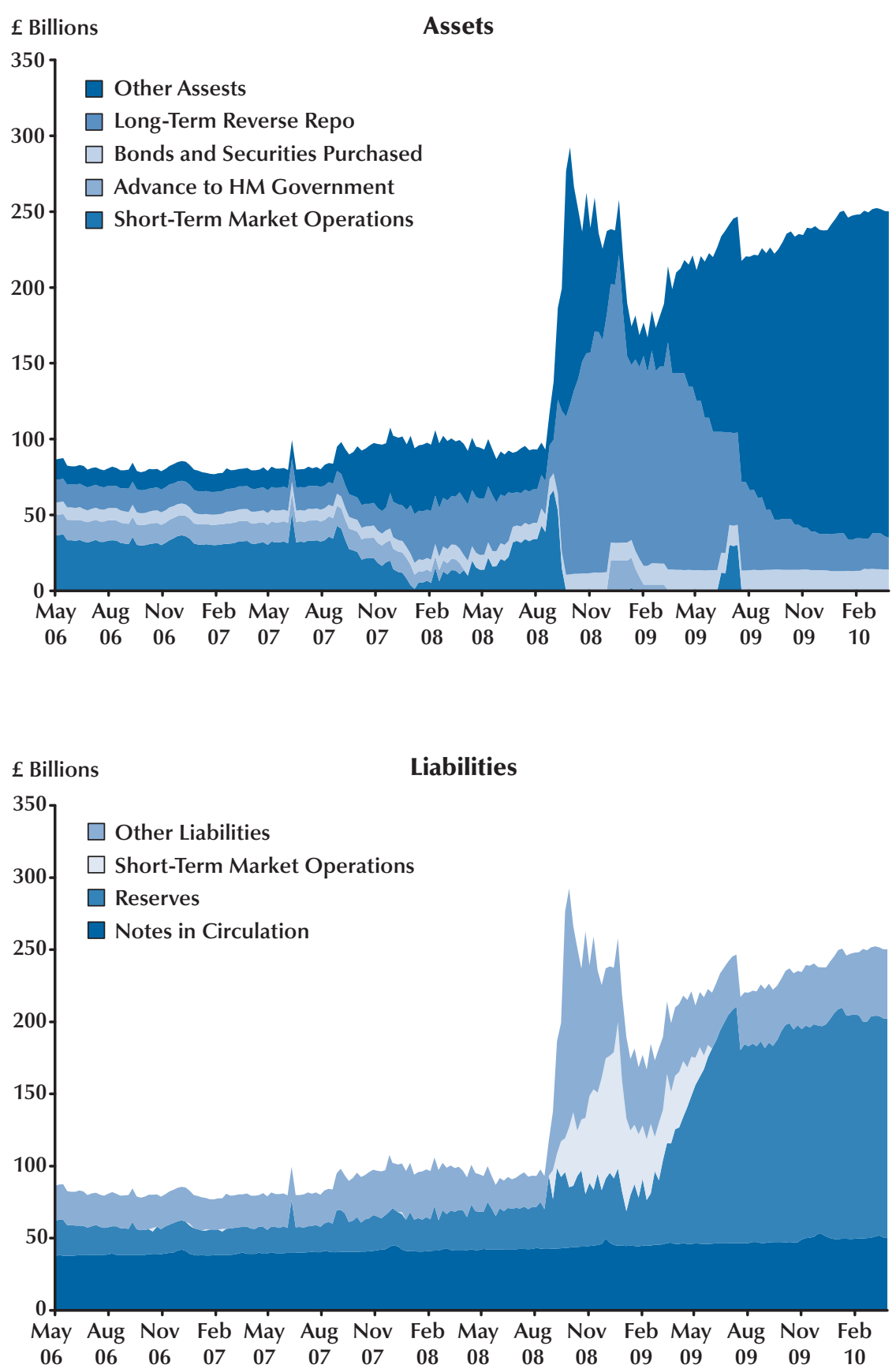

SOURCE: Bank of England (www.bankofengland.co.uk/markets/balancesheet/). 
On the asset side of the balance sheet, the large increase in the "Long-Term Reverse Repo" category reflects the assets acquired by expanding the types of collateral that may be pledged on traditional lending facilities. The later increase in the "Other Assets" category reflects the BOE's increase in dollar lending and assets purchased under the Asset Purchase Facility. On the liabilities side of the BOE's balance sheet, the monetary base is measured as the sum of "Notes in Circulation" plus "Reserves" at the BOE. Note that the BOE issues liabilities (BOE bills) that are not part of the monetary base as we have measured it in this analysis. During the fall of 2008, the BOE issued 1-week maturity bills to finance expanded lending to banks. The BOE shifted away from using its own bills for financing during 2009, causing liabilities in the "Short-Term Market Operations" category to decline and bank reserves to increase.

The BOE reports that balance-sheet actions reduced yields on medium- and long-dated government bonds, as well as spreads of commercial paper and commercial bonds over overnight index swaps. Yields on 10-year U.K. bonds fell when purchase programs were announced and subsequently drifted upward as purchases occurred. Inflation expectations plummeted from a high of 4.5 percent in September 2008 to a low of 1 percent (see the dashed line in Figure 3) before later drifting and leveling off near 2 percent.

\section{Switzerland}

The impact of the global financial crisis on Switzerland has been modest, albeit sufficient to result in recession. During 2008:Q4 and 2009:Q1, real gross domestic product (GDP) declined at an annual rate of 2.5 percent and 3.5 percent, respectively. The Swiss National Bank's (SNB) 2009

Financial Stability Report describes the steps they took. ${ }^{12}$ In October 2008 the SNB reduced its target for the 3-month Swiss franc London Interbank offering rate (LIBOR) and began expanding its balance sheet. The SNB also began participating in foreign currency swaps with the Federal

\footnotetext{
${ }^{12}$ For additional details, see Swiss National Bank (2009); all quotations in this section are from this report.
}

Reserve in October 2008, eventually reaching more than CHF 60 billion in March 2009. In December 2008 the SNB created a loan stabilization fund to "finance the acquisition of illiquid assets from UBS, largely composed of assets backed by US residential and commercial mortgages." Under terms of the loan, UBS, among other financial institutions, will make partial payments extending up to 12 years. (Assets in this program were CHF 22 billion as of September 2009.) Between October 2008 and April 2009, the Swiss monetary base approximately tripled, reaching CHF 117 billion in April 2009. On March 12, 2009, the SNB announced a policy shift toward foreign exchange market intervention, saying the appreciation of the Swiss franc "represents an inappropriate tightening of monetary conditions."

The SNB's unconventional policies sharply increased the size of its balance sheet and the Swiss monetary base. Figure 6 shows the growth and changing composition of the SNB assets and liabilities. The largest increase among assets is in foreign currency swap transactions. On the liabilities side, the largest increase is in bank deposits at the SNB (top category on the graph)-from an average of CHF 6 billion in 2007 to more than CHF 75 billion in March 2009. To temper the increase in the monetary base and "absorb liquidity in the market" resulting from unconventional monetary policies, the SNB began issuing its own debt in October 2008 (labeled as "SNB Debt Certificates” in Figure 6). As of September 2009, the SNB had CHF 25 billion outstanding in SNB notes. These notes have a maximum maturity of one month.

Although we cannot yet assess the impact, if any, of the monetary base expansion on inflation, it seems reasonable to explore the SNB's inflation forecasts underlying its policy actions. In March 2009, the SNB forecast deflation for most of 2009 and close to zero inflation in 2010 and 2011. The forecast six months later projects deflation only in early 2009 and 2 percent inflation by the end of 2011. Perhaps tripling the monetary base has forestalled further undesired decreases in inflation (or even deflation): Inflation expectations plummeted in mid-2008, reaching close to zero 
Figure 6

\section{Composition of the Swiss National Bank Balance Sheet}
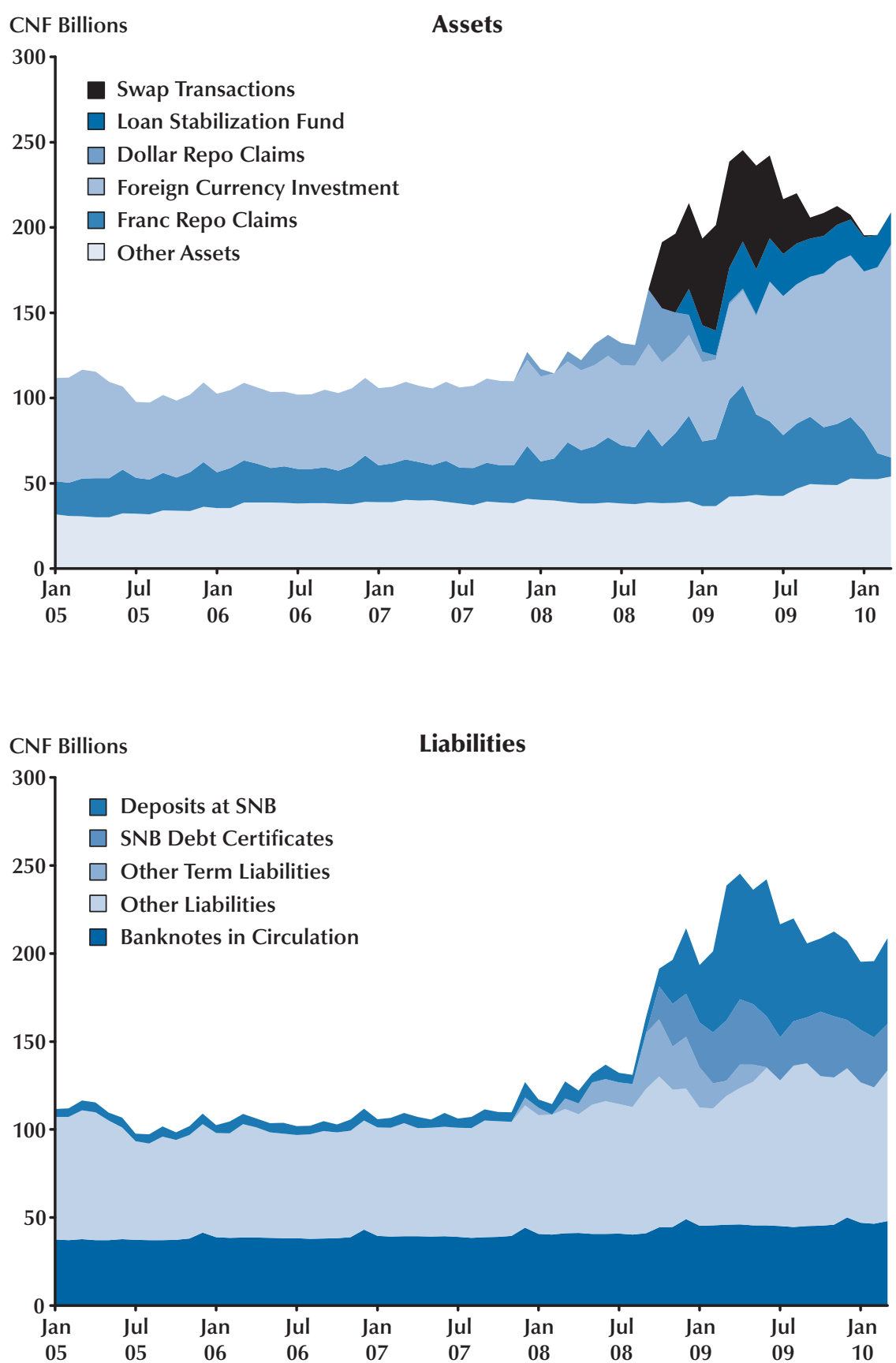

SOURCE: Swiss National Bank. 
percent by March 2009 (see Figure 3). Expected inflation has been positive and slowly trending upward since the SNB began quantitative easing.

\section{Japan}

Japan's economic growth has slowed sharply since the bursting of the asset price bubble in the early 1990s-from a 5.1 percent annual rate during the latter half of the 1980 s, to a 1.5 percent annual rate during the 1990s, to a less than 0.5 percent annual rate since $2000 .{ }^{13}$ Here, we review three episodes of BOJ quantitative easing effortsthe zero interest rate policy of the 1990s, a quantitative easing policy from 2001 to 2006 , and its actions in response to the most recent financial crisis.

During the 1990s, the BOJ adopted the "zero interest rate policy" regime in which the policy target rate (overnight call rate) was set at 0.1 percent. The BOJ maintained its balance sheet at a level just sufficient to sustain the overnight call rate (near) zero. Nevertheless, real GDP growth during the decade averaged only 1.5 percent per year and the economy was stagnant at the decade's end. Worse, the threat of deflation had not easedyear-over-year consumer price index (CPI) inflation was negative (see Figure 3).

In March 2001, with a policy rate at zero, the BOJ initiated a quantitative easing policy in which it would maintain the call rate at zero until the year-over-year increase in the CPI "became positive on a sustained basis." 14 The expansion of the balance sheet was regulated by a targeted level of current account balances held by banks at the BOJ. To achieve its targets, the BOJ purchased government securities and bank bills backed by eligible collateral (i.e., corporate bonds or commercial paper). The BOJ more or less smoothly increased its holdings of long-term Japanese government bonds (JGBs); its holdings doubled by 2006 to roughly $¥ 90$ trillion. In contrast, the BOJ purchased bank bills to quickly increase its bal-

\footnotetext{
${ }^{13}$ Shirakawa (2010) argues that quantitative easing policy actions successfully boosted Japanese economic activity and the story of "The Lost Decade" is myth.

${ }^{14}$ For details, see Oda and Ueda (2007) or Maeda et al. (2005). Humpage and Shenk (2008) provide a very readable summary. Shiratsuka (2009) summarizes recent thought.
}

ance sheet, reaching roughly $¥ 40$ trillion in 2006 (Figure 7). The BOJ began a two-tier exit strategy in 2006 when the CPI displayed signs of steady increase, allowing its holdings of bank bills and long-term government securities (JGBs) to run off. Empirical studies have concluded that the BOJ's policy actions reduced longer-term rates, thereby flattening the yield curve, and had a positive, but small, effect on economic growth (Ugai, 2007).

In response to the current financial crisis, the $\mathrm{BOJ}$ reduced its policy target rate to 0.3 percent from 0.5 percent on October 31, 2008, and to 0.1 percent on December 19, 2008, and has initiated or expanded several programs to provide funds to the market. ${ }^{15}$ Commercial paper was purchased outright during 2009:Q1 (¥1.6 trillion) but a rapid runoff occurred during the second quarter, and corporate bond purchases were made during the third quarter ( $¥ 400$ billion). In addition, approximately $¥ 4$ trillion of commercial paper was purchased during the first quarter under repo, and approximately $¥ 6$ trillion in "special funds" was provided to banks as advances against corporate debt as collateral. These combined actions were modest relative to the size of the BOJ's balance sheet (see Figure 7).

In November 2009, the BOJ declared that the economy had officially entered a period of deflation with a negative year-over-year change in the CPI. On December 1, 2009, the BOJ announced a new liquidity supply initiative to fight weak economic activity, deflation, and a rising yen exchange rate. This program calls for the BOJ to furnish up to $¥ 10$ trillion in 3-month loans to banks at the 0.1 percent target level of the policy rate (overnight unsecured call rate) against a variety of collateral, including JGBs, corporate bonds, and commercial paper. The BOJ said the program should "further enhance easy monetary conditions" and "encourage a further decline in longer term interest rates.” Deflation continues in Japan, however, with a pace of -1 percent per year as of April 2010 (see Nishimura, 2010).

\footnotetext{
15 The BOJ's actions as of April 2010 are well summarized in "The Bank of Japan's Policy Measures in the Current Financial Crisis" (www.boj.or.jp/en/type/exp/seisaku cfc/index.htm).
} 
Figure 7

\section{Composition of Bank of Japan Balance Sheet}

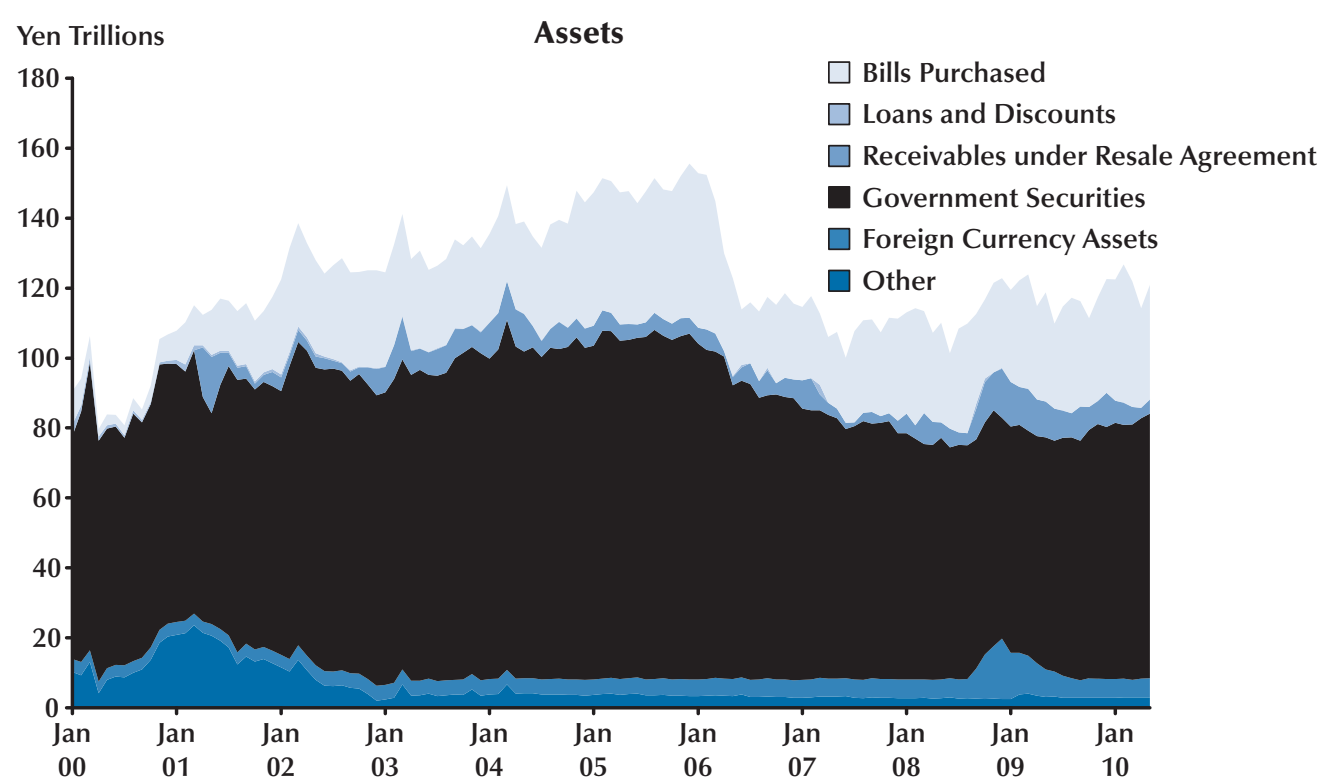

Yen Trillions

Liabilities

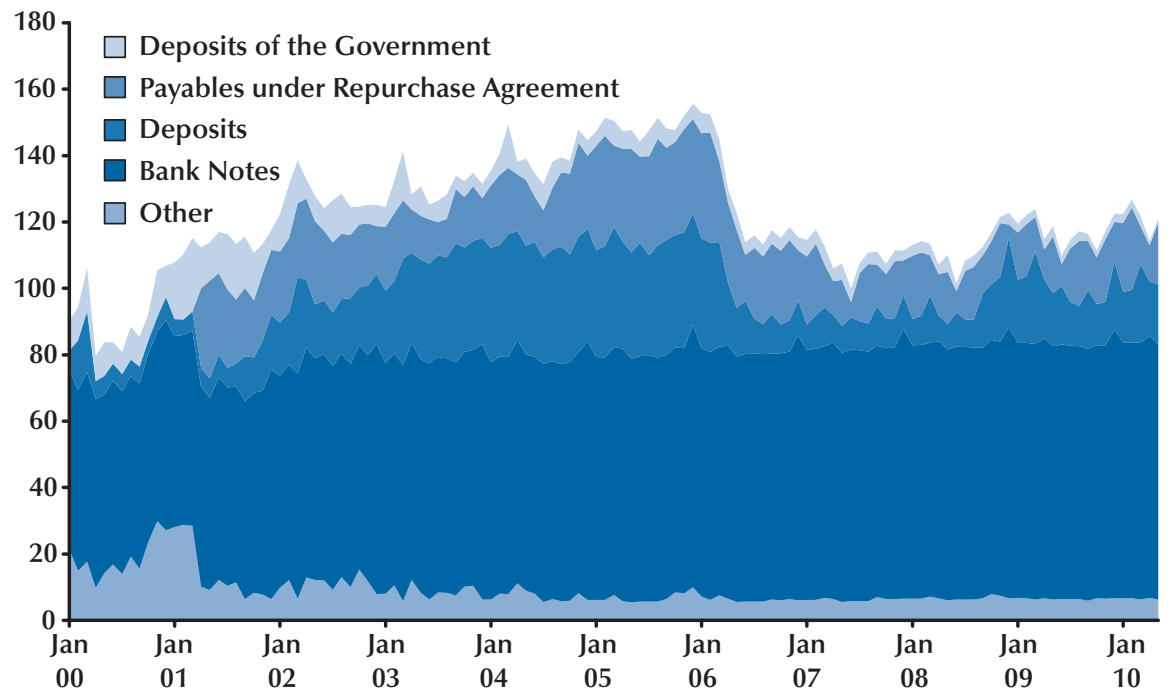

NOTE: The monetary base of Japan is approximately the sum of banknotes in circulation outside the BOJ plus deposits held by banks at the BOJ.

SOURCE: Bank of Japan. 


\section{Scandinavia}

Sweden and Finland provide a unique set of cases because they have each undergone two episodes of quantitative easing during the past two decades: once during the banking crisis of the 1990s and more recently during the 2007-09 financial crisis. They are excellent case studies of how to do it right.

Sweden. Sweden was affected by two severe financial crises during the past two decades: the 1990s Nordic banking crisis and the 2007-08 global financial crisis. Each time, the Riksbank used large-scale increases in its balance sheet as a policy tool; the monetary base more than doubled during the Nordic banking crisis and has tripled during the most recent global financial crisis.

The Nordic banking crisis of the early 1990s affected all Scandinavian countries. ${ }^{16}$ In each country, central bank support to the banking system sharply increased the nation's monetary base. Starting in 1992, the Riksbank used its foreign currency reserves to provide liquidity support to banks. Because the government had guaranteed all bank debt, the Riksbank allowed banks to borrow freely through normal liquidity facilities. The monetary base more than doubled within 10 months-from SEK 83.73 billion in August 1993 to SEK 208.26 billion in June 1994. When conditions stabilized, the monetary base decreased rapidly to SEK 81.11 billion by February 1997. Although inflation did not increase significantly during or after the monetary base expansion period, CPI inflation during 1994 was more than double the Riksbank's 2 percent inflation target and inflation expectations increased modestly as the Riksbank expanded its balance sheet. As a result, even with the monetary base at elevated levels, the Riksbank gradually increased its policy target rate during 1994 and 1995. The inflation rate returned to a 2 percent pace by late 1995 , slipping negatively the following year. Inflation expectations retreated below the Riksbank's 2 percent inflation target to near 1.5 percent.

\footnotetext{
${ }^{16}$ Honkapohja (2009) and Anderson (2009) discuss causes and the
} policy response; see also the references cited therein.
Policy actions by the Riksbank during the recent financial crisis resemble those during the 1990s. The growth and composition of the Riksbank's balance sheet are shown in Figure 8. In September 2008, the Riksbank created a loan facility that provided access to U.S. dollars, funded by currency swap agreements with the Federal Reserve. ${ }^{17}$ This program increased the balancesheet asset item "Claims on Residents inside Sweden Denominated in Foreign Currency" and the liability item "Liabilities outside Sweden Denominated in Kronor." To further assist banks, in October 2008 the Riksbank created an additional loan facility designed to accept collateral with maturities longer than those accepted at its traditional lending facilities.

To fund some lending programs, the Riksbank issued debt-Riksbank certificates - with a maturity of one week. The Riksbank, unlike other central banks, includes these certificates in its measure of the monetary base (see Figure 8). ${ }^{18}$ Based on this measure, Sweden's monetary base increased almost fivefold from SEK 105.92 billion in September 2008 to a peak in November 2009. Alternatively, measured using the commonplace definition of the monetary base as the sum of currency in circulation plus the deposits held by financial institutions at the central bank, Sweden's monetary base tripled to peak of SEK 319 billion in December 2008.

Finland. Finland likely was the country most severely affected by the Nordic banking crisis, recording decreases in real GDP growth for three consecutive years (1990:Q3-1993:Q3). ${ }^{19}$ From 1992 to 1997, strong government intervention included equity investments in the nation's

\footnotetext{
${ }^{17}$ For details, see Öberg (2009).

${ }^{18}$ For comparison purposes, the data in Figure 1 report a measure of the monetary base without Riksbank certificates.

19 The Bank of Finland's takeover of the shaky commercial bank Skopbank in the fall of 1991 perhaps was the climax of the country's financial crisis. Skopbank was one of the pillars of Finland's commercial banking industry, widely referred to as the "central bank” for the country's savings banks. The takeover is reported to have eventually cost FIM 15 billion, the equivalent of 3 percent of GDP in 1991 (Sandal, 2004). The eventual resolution of the crisis and unwinding of government support programs cost Finland an amount equal to approximately 6 percent of one year's GDP; for Sweden and Norway, the eventual cost was near zero. For additional details, see Anderson (2009).
} 
Figure 8

\section{Composition of the Riksbank's Balance Sheet}
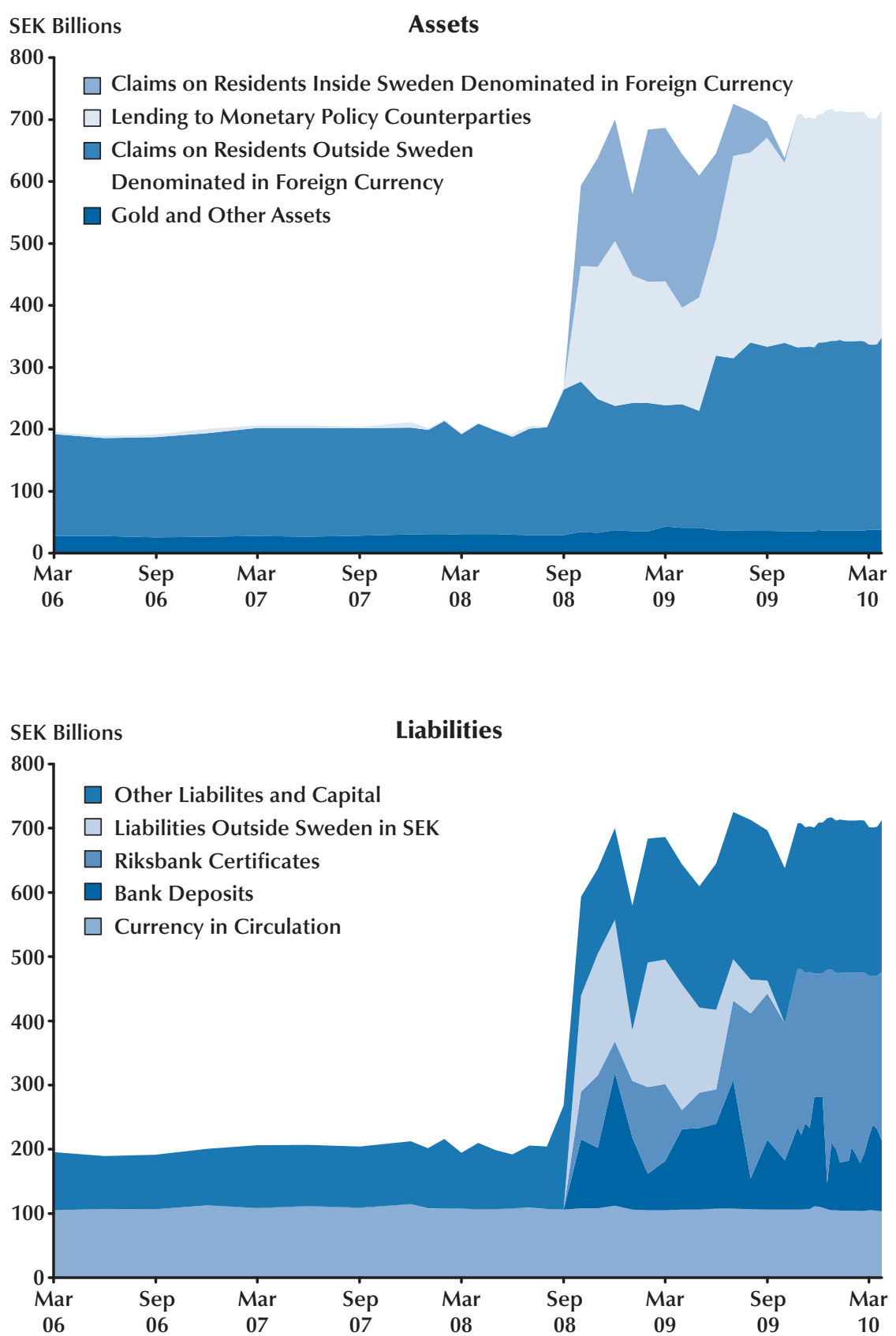

NOTE: The Riksbank defines Sweden's monetary base as "Currency in Circulation" plus "Bank Deposits" and "Riksbank Certificates." SOURCE: The Riksbank. 


\section{Figure 9}

\section{Composition of Bank of Finland's Balance Sheet}
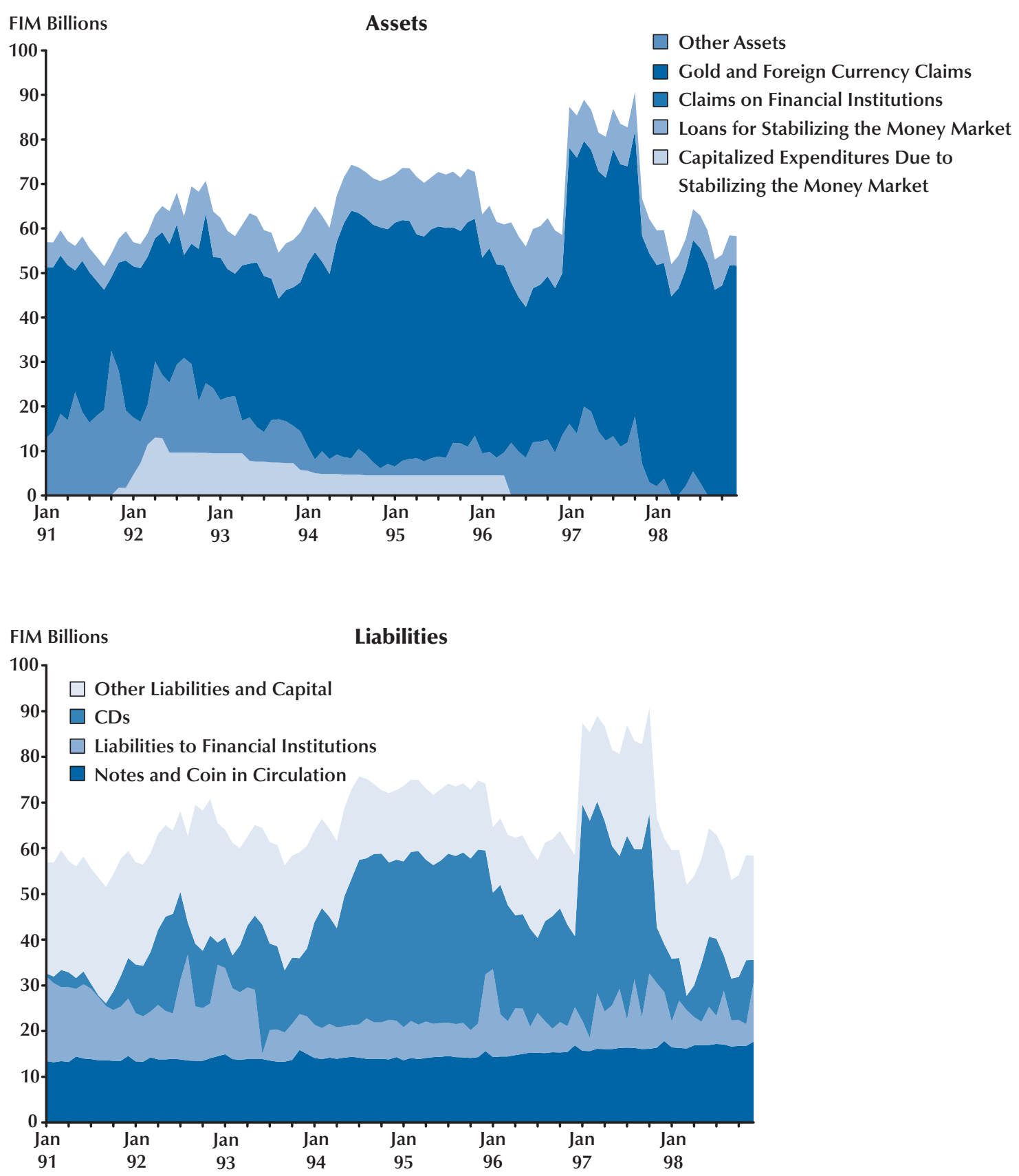

SOURCE: Bank of Finland. 
banks and in a government-funded bank guarantee fund. By the end of 1997, the government had extended FIM 43 billion in direct bank support. ${ }^{20}$ The Finnish monetary base expanded from FIM 34.5 billion in January 1992 to FIM 68.7 billion in March 1997 (Figure 9). Banking institutions started repaying the government in October 1997; thereafter, the monetary base decreased rapidly to FIM 36.2 billion in December 1997.

Inflation in Finland was high before the banking crisis started: The monthly year-over-year CPI rate topped 7 percent in spring 1990 and stayed above 5 percent during 1990. Inflation subsided as the crisis deepened; the year-over-year rate fell below 2 percent (the Bank of Finland's inflation target) in mid-1993. Inflation remained low for the remainder of the 1990s and inflation expectations remained anchored between 2 and 2.5 percent.

Finland adopted the euro in 1999, and hence during the financial crisis of 2007-09 exercised no independent monetary policy. Its response has been limited to banking supervision and support (Liikanen, 2009). Perhaps the largest country-specific impact was the spinoff of the Finnish operations of the Icelandic bank Glitnir into a new Finnish corporation in October 2008.

\section{OTHER CASES OF LARGE-SCALE BALANCE-SHEET INCREASES}

In this section, we briefly examine the experiences of three other countries with recent largescale central bank balance-sheet increases.

\section{Australia}

Australia experienced a sharp but mild recession during late 2008 and early 2009, caused in part by reduced export demand and weaker consumer confidence. Stevens (2009) notes that the Reserve Bank of Australia had started easing policy in early September due to moderating demand, reducing its target overnight rate from 7.25 percent to 7 percent. Easing accelerated after the Lehman Brothers failure; the target was

${ }^{20}$ For details, see Mutikainen (1998). reduced by 300 basis points during the last four months of 2008 (including a 100-basis-point cut on October 8, 2008, coordinated with 50-basispoint or larger reductions by other G-10 central banks). Private net capital flows were negative in the third and fourth quarters of 2008, in part because Australian banks found Federal Reserve foreign currency swap lines a lower-cost source of funds than alternatives, particularly in 2008:Q4. ${ }^{21}$ By mid-2009, global short-term credit markets were normalizing and Australian banks were obtaining funds in the market below the cost of the Fed's swap facility. The policy target rate reached its low of 3 percent on April 8, 2009, and on October 7, 2009, the Research Bank of Australia (RBA) started the process of increasing its target rate toward "a more normal setting" with a 25-basis-point increase.

The RBA's policy actions do not merit the label "quantitative easing" because the policy target rate never reached zero during mid-2009. Yet, the RBA balance sheet expanded sharply between August and December 2008, resulting in a 54 percent increase in the monetary base (measured as the sum of "Reserves and Notes" plus "Term Deposits"). Figure 10 shows the growth and changing composition of the RBA balance sheet. A number of domestic programs affected the balance sheet, including (i) broadening the pool of eligible collateral accepted by the RBA, (ii) conducting open market operations at longer maturities to increase the impact on longer-term yields, and (iii) offering term deposits at the RBA. ${ }^{22}$ Deposits obtained by the RBA under the Federal Reserve's swap lines are included in the asset "Gold and Foreign Exchange," whereas the Australian dollars held as collateral by the Federal Reserve are included in the liability item "Deposits of Overseas Institutions.” Interestingly, the RBA unwound its balance-sheet expansion in the first half of 2009 without rapid increases in its policy target rate: By May 2009, the level of the monetary base had returned approximately to its trend with the policy target rate at 4.25 percent.

\footnotetext{
${ }^{21}$ D'Arcy and Ossolinski (2009) report that some Australian banks, successful bidders for U.S. dollars at RBA auctions, apparently reloaned the dollar funds to foreign parents.

${ }^{22}$ For additional details, see Stevens (2010) and Debelle (2008).
} 
Figure 10

\section{Composition of Reserve Bank of Australia Balance Sheet}
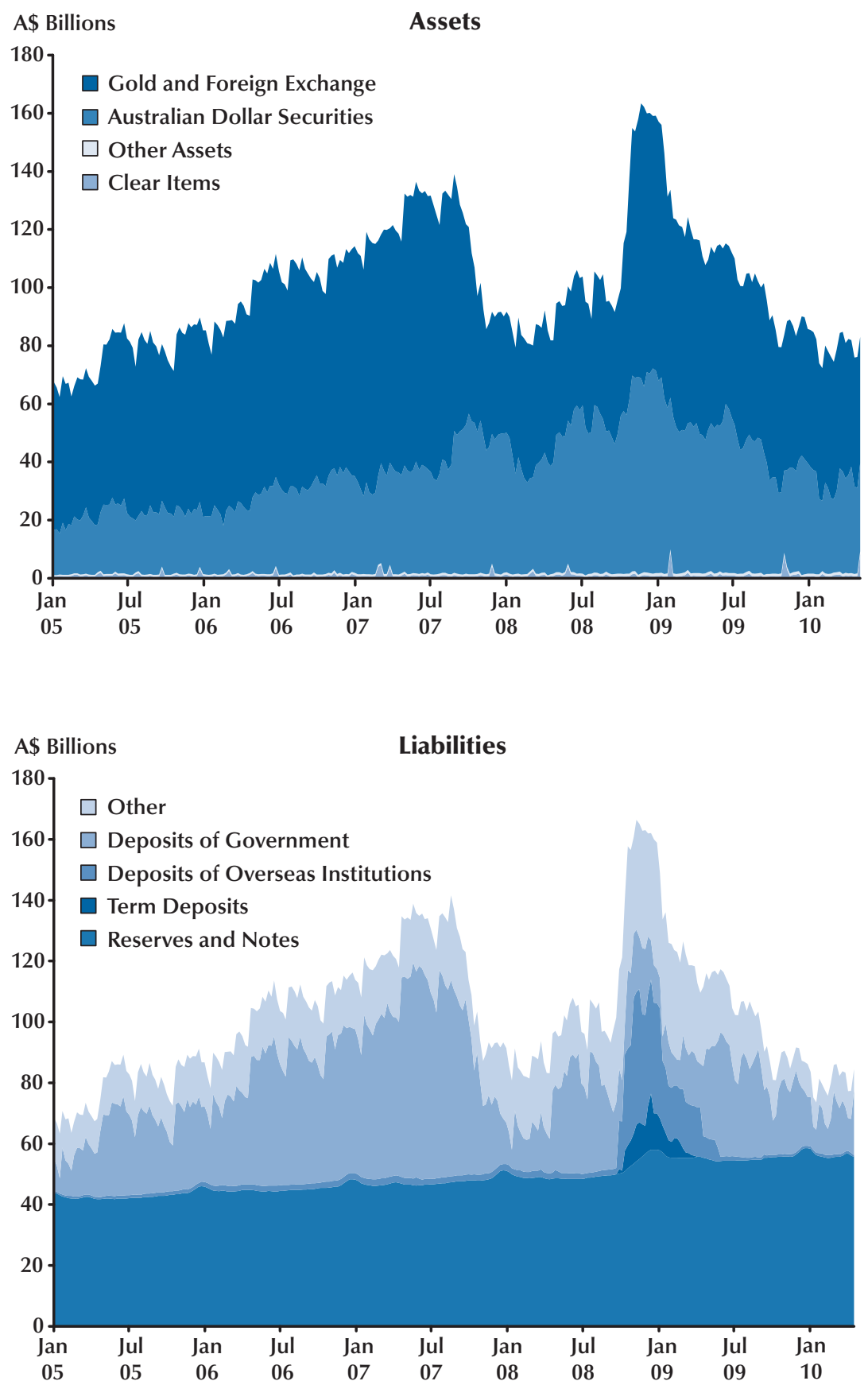

NOTE: The monetary base of Australia is approximately equal to "Reserves and Notes" plus "Term Deposits." SOURCE: Reserve Bank of Australia. 


\section{Anderson, Gascon, Liu}

There is no evidence that the RBA's actions affected inflation. Before the crisis, the Australian economy had experienced year-over-year growth in consumer prices averaging just under 3 percent, within the RBA's target range of 2 to 3 percent. Inflation expectations, however, reached as high as 6 percent as Australia's business cycle peaked in May 2008 (see Figure 3), but the late 2008 disturbances in financial markets caused inflation expectations to decline precipitously. Unlike in the United States, United Kingdom, and Japan, inflation expectations in Australia never raised the specter of deflation. A prompt unwinding of its balance sheet appears to have protected inflation stability.

\section{Iceland}

We mention Iceland primarily because of its widely reported role in the banking crises of several European nations. Iceland is unusual, in this analysis, because its policy target rate and central bank balance sheet increased simultaneously.

Iceland's financial system was seriously harmed by the recent financial crisis. Three of the country's largest commercial banks failed in October 2008; the government assumed the role as insurer of their deposits and replaced each board of directors. ${ }^{23}$ These banks, however, had customer liabilities with other countries in addition to Iceland, equal to roughly 10 times Iceland's annual gross national product (see Central Bank of Iceland [CBI], 2009b, p. 13). As a result of the bank failures, Iceland's exchange rate fell sharply in October 2008; Iceland obtained a $\$ 2.1$ billion loan from the International Monetary Fund (IMF) to stabilize its financial system.

Before receiving the IMF loan to stabilize the country's economy, in January 2008 the CBI had expanded the list of eligible collateral at its regular lending facilities to include bonds issued in dollars, euros, or British pounds but continued to require that at least 50 percent of collateral be denominated in kronor. By August 2008, the CBI went a step further, expanding the list of eligible collateral to include asset-backed securities and

${ }^{23}$ For additional details, see Central Bank of Iceland (2009a). reducing the krona requirement to 30 percent. Bank runs began the first week of October: Currency in circulation increased 53 percent that week (see Central Bank of Iceland, 2009b, pp. 24-25). The CBI used its reserves-even old banknotes no longer intended for circulationto meet public demand. The combination of increased loans to banks ${ }^{24}$ and currency in circulation caused the CBI's balance sheet to increase rapidly during the fall of 2008. At its peak, Iceland's monetary base had increased by 70 percent with highly volatile swings from month to month.

The CBI sought to distinguish its traditional approach to monetary policy (targeting the discount rate) from its balance-sheet actions. In October 2008, for example, the CBI increased its policy rate (the nominal discount rate) from 12 percent to 18 percent. At this time, year-over-year inflation had been steadily increasing since 2007 and was close to 15 percent. In pursuing its inflation target of 2.5 percent, the CBI had held its policy rate above 10 percent since $2005 .{ }^{25}$ The CBI changed course in March 2009 after inflation began to subside (albeit still at high levels). The nominal discount rate dropped to 11 percent in November 2009. Because inflation was well above the target at the beginning of the crisis, it is difficult to assess whether the balance-sheet expansion affected either actual or expected inflation. However, the CBI forecasts that inflation will reach its target of 2.5 percent sometime in early 2011 (Central Bank of Iceland, 2009b), suggesting that the monetary base increases are not anticipated to increase inflation pressures.

\section{New Zealand 26}

New Zealand's monetary base increased 138 percent between July and December 2006. No adverse "shock" to the economy caused the Reserve Bank of New Zealand (RBNZ) to increase its monetary base. Rather, the increase was the

\footnotetext{
${ }^{24}$ Iceland's treasury purchased a 75 percent share in one bank (Glitnir) for $€ 600$ million and a week later the CBI loaned $€ 500$ million to another bank (Kaupthing) for four days.

${ }^{25}$ The CBI adopted an inflation target in March 2001.

${ }^{26}$ For additional details, see Nield (2008).
} 


\section{Figure 11}

\section{Composition of Reserve Bank of New Zealand Balance Sheet}
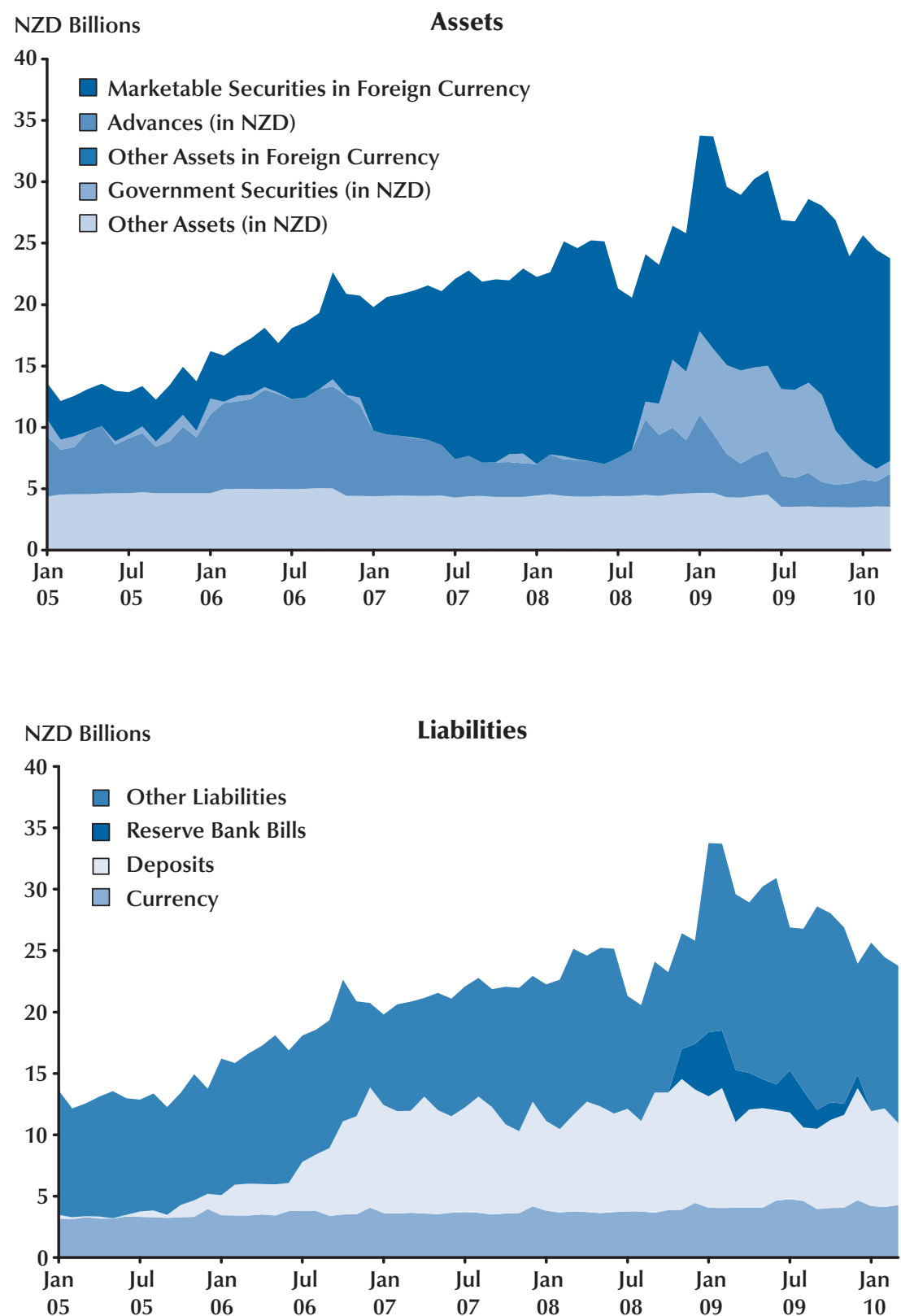

NOTE: The Reserve Bank of New Zealand does not publish a series on the monetary base. It does publish data on settlement institution deposits at the RBNZ and currency in circulation, the sum of which is a measure of the monetary base.

SOURCE: Reserve Bank of New Zealand. 


\section{Anderson, Gascon, Liu}

culmination of a collaborative project between the Reserve Bank and the settlement banks to improve the payment system to "reduce risk and enhance certainty in the financial system" (Nield, 2008, p. 10). The RBNZ-operated payment system does not permit daylight overdrafts (i.e., payments on behalf of a bank that exceed the bank's available account balance at the RBNZ). Increased settlement balances at the RBNZ significantly reduced delays in the payment system. The RBNZ also began paying interest on its settlement balances to increase the acceptance of the system and to discourage banks from using these reserve balances to fund new lending.

The new settlement system was implemented between August and October 2006. The RBNZ expected the monetary base would increase to between NZ\$7 billion and NZ\$10 billion (Nield, 2008) as banks gradually unwound Treasury bill holdings and used foreign exchange swaps to purchase New Zealand dollars. The RBNZ determined that since the cash was purchased at rates consistent with the policy rate, there would be no inflationary pressures. In fact, year-over-year growth in consumer prices fell from 3.4 percent in 2006:Q3 to 1.8 percent in 2007:Q3. It did, however, increase to 5 percent in 2008:Q3 only to again drop under 2 percent in 2009:Q2. Over the same period, inflation expectations remained well anchored around 3 percent.

The financial crisis hit New Zealand in mid2008. Between July 2008 and April 2009, as inflation expectations plummeted, the RBNZ reduced its target for the official cash rate to 2.5 percent from 8.25 percent. Although the RBNZ has not emphasized increases in its balance sheet as part of its policy, Figure 11 shows clearly that large balance-sheet increases did occur. More recently, the RBNZ balance sheet has contracted somewhat as the crisis has eased, although a weak economic outlook has caused the RBNZ to sustain a low policy target rate.

\section{CONCLUSION}

During the past two decades, large increasesand decreases-in central bank balance sheets have become a viable monetary policy tool. Historically, doubling or tripling a country's monetary base was a recipe for certain higher inflation. Often such increases occurred only as part of a failed fiscal policy or, perhaps, as part of a policy to defend the exchange rate. Both economic models and central bank experience during the past two decades suggest that such changes are useful policy tools if the public understands the increase is temporary and if the central bank has some credibility with respect to desiring a low, stable rate of inflation. We find little increased inflation impact from such expansions.

For monetary policy, our study suggests several findings:

(i) A large increase in a nation's balance sheet over a short time can be stimulative.

(ii) The reasons for the action should be communicated. Inflation expectations do not move if households and firms understand the reason(s) for policy actions so long as the central bank can credibly commit to unwinding the expansion when appropriate.

(iii) The type of assets purchased matters less than the balance-sheet expansion.

(iv) When the crisis has passed, the balance sheet should be unwound promptly. 


\section{REFERENCES}

Anderson, Richard G. "Resolving a Banking Crisis, the Nordic Way." Federal Reserve Bank of St. Louis Economic Synopses, 2009, No. 10, February 18, 2009; http://research.stlouisfed.org/publications/es/09/ES0910.pdf.

Bank of England. "Asset Purchase Facility.” 2009a; www.bankofengland.co.uk/markets/apf/index.htm.

Bank of England. "Quantitative Easing Explained.” 2009b; www.bankofengland.co.uk/monetarypolicy/assetpurchases.htm.

Bank of Finland. Bank of Finland Annual Report 2008. March 2009; www.bof.fi/NR/rdonlyres/19D57A56-427D-4A21-B3CB-0D3B32217A59/0/VK08E.pdf.

Barro, Robert J. "Rational Expectations and the Role of Monetary Policy." Journal of Monetary Economics, January 1976, 2(1), pp. 1-32.

Batchelor, Roy A. and Dua, Pami. "Household versus Economist Forecasts of Inflation: A Reassessment: Note." Journal of Money, Credit, and Banking, May 1989, 21(2), pp. 252-257.

Berentsen, Aleksander and Waller, Christopher. "Price Level Targeting and Stabilization Policy.” Working Paper No. 2009-033B, Federal Reserve Bank of St. Louis, revised October 2009;

http://research.stlouisfed.org/wp/2009/2009-033.pdf (forthcoming in Journal of Money, Credit, and Banking).

Bernanke, Ben S. “The Federal Reserve’s Balance Sheet: An Update.” Speech at the Federal Reserve Board Conference on Key Developments in Monetary Policy, Washington, DC, October 8, 2009; www.federalreserve.gov/newsevents/speech/bernanke20091008a.htm.

Bernanke, Ben S. and Reinhart, Vincent R. "Conducting Monetary Policy at Very Low Short-Term Interest Rates." American Economic Review, May 2004, 94(2), pp. 85-90.

Bernanke, Ben S.; Reinhart, Vincent R. and Sack, Brian P. "Monetary Policy Alternatives at the Zero Bound: An Empirical Assessment.” Brookings Papers on Economic Activity, 2004, 2, pp. 1-78.

Borio, Claudio and Disyatat, Piti. "Unconventional Monetary Policies: An Appraisal.” BIS Working Papers No. 292, Bank for International Settlements, November 2009; www.bis.org/publ/work292.pdf.

Central Bank of Iceland. Annual Report 2008. 2009a; www.sedlabanki.is/lisalib/getfile.aspx?itemid=7076.

Central Bank of Iceland. Financial Stability Report 2009. October 6, 2009b; www.sedlabanki.is/?PageID=1061.

Crowe, Christopher and Meade, Ellen E. "Central Bank Independence and Transparency: Evolution and Effectiveness.” European Journal of Political Economy, December 2008, 24(4), pp. 763-77.

Clarida, Richard; Galí, Jordi and Gertler, Mark. "The Science of Monetary Policy: A New Keynesian Perspective.” Journal of Economic Literature, December 1999, 37(4), pp. 1661-707.

Cúrdia, Vasco and Woodford, Michael. "The Central-Bank Balance Sheet as an Instrument of Monetary Policy." Prepared for Carnegie-Rochester Conference on Public Policy, "The Future of Central Banking," April 16-17, 2010a; www.carnegie-rochester.rochester.edu/april10-pdfs/Curdia\%20Woodford.pdf.

Cúrdia, Vasco and Woodford, Michael. "Conventional and Unconventional Monetary Policy." Federal Reserve Bank of St. Louis Review, July/August 92(4), 2010b; http://research.stlouisfed.org/publications/review/10/07/Curdia.pdf.

D’Arcy, Patrick and Ossolinski, Crystal. "Australian Capital Flows and the Financial Crisis.” Reserve Bank of Australia Bulletin, November 2009, pp. 1-6; www.rba.gov.au/publications/bulletin/2009/nov/pdf/bu-1109-1.pdf.

Debelle, Guy. "Market Operations in the Past Year." Presented at the 2008 FTA Congress, Melbourne, Australia, October 31, 2008, Reserve Bank of Australia; www.rba.gov.au/speeches/2008/sp-ag-311008.html. 


\section{Anderson, Gascon, Liu}

Gertler, Mark and Karadi, Peter. “A Model of Unconventional Monetary Policy.” Unpublished manuscript, New York University, April 2009; www.econ.nyu.edu/user/gertlerm/gertlerkaradiapril2010conference.pdf.

Goodfriend, Marvin S. and King, Robert G. "A Note on the Neutrality of Temporary Monetary Disturbances." Journal of Monetary Economics, 1981, 7(3), pp. 371-85.

Humpage, Owen F. and Shenk, Michael. “Japan’s Quantitative Easing Policy.” Federal Reserve Bank of Cleveland Economic Trends, December 10, 2008; www.clevelandfed.org/research/trends/2008/1208/01intmar.cfm.

Honkapohja, Seppo. “The 1990's Financial Crises in Nordic Countries.” Bank of Finland Research Discussion Papers No. 5, 2009.

Jeanne, Olivier and Svensson, Lars E.O. "Credible Commitment to Optimal Escape from a Liquidity Trap: The Role of the Balance Sheet of an Independent Central Bank.” American Economic Review, March 2007, 97(1), pp. 474-90.

Laurens, Bernard J.; Arnone, Marco and Seglaotto, Jean-Francois. Central Bank Independence, Accountability, and Transparency. Hampshire, UK: Palgrave Macmillan, 2009.

Liikanen, Erkki. "Central Banking in a Global Financial Crisis.” Presented at the Finnish Economic Association meeting, January 29, 2009; www.bof.fi/en/suomen pankki/ajankohtaista/puheet/2009/EL puhe29012009.htm.

Maeda, Eiji; Fujiwara, Bunya; Mineshima, Aiko and Taniguchi, Ken. "Japan’s Open Market Operations under the Quantitative Easing Policy.” Bank of Japan Working Paper Series No. 05-E-3, April 8, 2005;

www.boj.or.jp/en/type/ronbun/ron/wps/data/wp05e03.pdf.

Meltzer, Allan. “The Origins of the Great Inflation.” Federal Reserve Bank of St. Louis Review, March/April 2005, 87(2, Part 2), pp. 145-75; http://research.stlouisfed.org/publications/review/05/03/part2/Meltzer.pdf.

Mutikainen, Tapio. “Recession, Economic Policy and Banking Crisis Management in Finland in the 1990's.” Ministry of Finance discussion paper, June 23, 1998;

www.vm.fi/vm/fi/04 julkaisut ja asiakirjat/03 muut asiakirjat/discussion paper.pdf.

Nield, Ian. "Evolution of the Reserve Bank’s Liquidity Facilities.” Reserve Bank of New Zealand Bulletin, December 2008, 71(4), pp. 5-17; www.rbnz.govt.nz/research/bulletin/2007 2011/2008dec71 4nield.pdf.

Nishimura, Kiyohiko G. “Japan’s Economy and Monetary Policy.” Speech at a Meeting with Business Leaders in Miyagi, April 21, 2010; www.boj.or.jp/en/type/press/koen07/data/ko1004d.pdf.

Öberg, Svante. "Sweden and the Financial Crisis." Speech at Carlson Investment Management, Stockholm, January 20, 2009; www.riksbank.com/templates/Page.aspx?id=30276.

Oda, Nobuyuki and Ueda, Kazuo. "The Effects of the Bank of Japan's Zero Interest Rate Commitment and Quantitative Monetary Easing on the Yield Curve: A Macro-Finance Approach.” Japanese Economic Review, 2007, 58(3), pp. 303-28.

Reis, Ricardo. "An Interpretation of the Unconventional U.S. Monetary Policy Response to the 2007-09 Crisis." Presented at the September 2009 Brookings Conference on Economic Activity. (Forthcoming in Brookings Papers on Economic Activity; August 2009 draft version available at www.brookings.edu/ /media/Files/Programs/ES/BPEA/2009 fall bpea papers/2009 fall bpea reis.pdf).

Sandal, Knut. "The Nordic Banking Crises in the Early 1990s—Resolution Methods and Fiscal Costs," in Thorvald G. Moe, Jon A. Solheim, and Bent Vale, eds., The Norwegian Banking Crisis (Norges Banks Skriftserie/Occasional Papers No. 33, 2004). Chap. 3. Oslo, Norway: Norges Bank, 2004, pp. 77-115; www.norges-bank.no/upload/import/publikasjoner/skriftserie/33/chapter3.pdf.

Sargent, Thomas U. "The Ends of Four Big Inflations," in Robert Hall, ed. Inflation: Causes and Effects. Chap. 2. Chicago: University of Chicago Press, 1982, pp. 41-92; www.nber.org/chapters/c11452.pdf. 
Shirakawa, Maasaki. "Uniqueness or Similarity? Japan's Post-Bubble Experience in Monetary Policy Studies." Keynote address at Second IJCB Fall Conference hosted by the Institute for Monetary and Economic Studies, the Bank of Japan. September 16, 2010; www.boj.or.jp/en/type/press/koen07/data/ko1009c.pdf.

Shiratsuka, Shigenori. "Size and Composition of the Central Bank Balance Sheet: Revisiting Japan's Experience of the Quantitative Easing Policy.” Bank of Japan, IMES Discussion Paper No. 2009-E-25, November 2009; www.imes.boj.or.jp/english/publication/edps/2009/09-E-25.pdf.

Söderström, Ulf and Westermark, Andreas. "Monetary Policy When the Interest Rate Is Zero.” Sveriges Riksbank Economic Review, 2, pp. 5-30; www.riksbank.se/upload/Dokument riksbank/Kat publicerat/Rapporter/2009/2009 2 pv eng.pdf.

Stevens, Glenn. "The Conduct of Monetary Policy in Crisis and Recovery.” Address to The John Curtin Institute of Public Policy and Financial Services Institute of Australasia Public Policy Breakfast Forum, Perth, Australia, October 15, 2009; www.rba.gov.au/speeches/2009/sp-gov-151009.html.

Stevens, Glenn. "Recent Financial Developments.” Address to ACI 2010 49th World Congress, Sydney, Australia, March 26, 2010; www.bis.org/review/r100330c.pdf.

Swiss National Bank. 2009 Financial Stability Report. June 2009; www.snb.ch/en/mmr/reference/stabrep 2009/source/stabrep 2009.en.pdf.

Ugai, Hiroshi. "Effects of the Quantitative Easing Policy: A Survey of Empirical Analyses.” Monetary and Economic Studies, March 2007, 25(1), pp. 1-48.

Woodford, Michael. "Inflation Targeting and Optimal Monetary Policy.” Federal Reserve Bank of St. Louis Review, July/August 2004, 86(4), pp. 15-41;

http://research.stlouisfed.org/publications/review/04/07/Woodford.pdf. 
